Multiple immune cells express IFNAR, but it is not known what the effect of IFN- stimulation is on each cell type and how that stimulation affects symptom presentation. We hypothesize that BIFNAR mice would be specifically protected from splenomegaly, B cell activation, and ANA production, due to IFN-s known ability to enhance the antibody response. Methods To examine the role of $\mathrm{B}$ cell responses to IFNstimulation in mouse lupus-like disease, we studied B cell specific IFNAR-deficiency (BIFNAR) in the B6.Nba2 spontaneous lupus-like disease model, using flow cytometry, ELISA, qRTPCR and Immunostainings. We also immunized the mice with NP-CGG or NP-Ficoll in complete Freunds adjuvant to determine the effect of IFNAR-expression by B cells during antibody responses to exogenous antigen.

Results At four months of age, BIFNAR mice displayed slightly reduced spleen sizes, although this decrease was not significant until nine months of age. Furthermore, starting at 4 months of age, BIFNAR mice displayed reduced levels of chromatin specific ANAs along with reduced populations of plasmablasts, plasma cells and activated B cells. All other measures of disease showed no difference including total IgG and IgM production, immune complex deposition and $\mathrm{C} 3$ complement fixation in the kidney glomeruli, and glomerular size. Somewhat surprising, antibody responses to T-dependent and T-independent immunizations were also not affected.

Conclusions IFN- stimulation on B cells contributed to splenomegaly, increased B cell activation and differentiation, and subsequent production of chromatin specific ANAs, but had no specific role in the response to exogenous antigen. Thus, IFN- remains a valid therapeutic target for SLE; especially in patients presenting with high ANAs.

Funding Source(s): R01AI118774

\section{PREDICTION OF FETAL LOSS IN PREGNANT PATIENTS WITH SYSTEMIC LUPUS ERYTHEMATOSUS}

${ }^{1}$ Jiayue Wu* , ${ }^{2}$ Wei-hong Zhang, ${ }^{1}$ Jinghang Ma, ${ }^{1}$ Chunde Bao, ${ }^{3}$ Jinlin Liu, ${ }^{1}$ Wen Di. ${ }^{1}$ Renji Hospital Affiliated to Shanghai Jiao Tong University School of Medicine; ${ }^{2}$ ICRH Gent University; ${ }^{3}$ School of Public Policy and Administration Xi'an Jiaotong University
Abstract 250 Table 1 Patients' characteristics during pregnancy

\begin{tabular}{|c|c|c|c|c|}
\hline Variables & $\begin{array}{l}\text { Total } \\
\mathrm{n}=338(\%)\end{array}$ & $\begin{array}{l}\text { Live birth } \\
\mathrm{n}=300(\%)\end{array}$ & $\begin{array}{l}\text { Fetal loss } \\
\mathrm{n}=38(\%)\end{array}$ & $P$ value \\
\hline \multicolumn{5}{|l|}{ Characteristics } \\
\hline Age $(y r$, mean $\pm S D)$ & $29.5 \pm 4.0$ & $29.7 \pm 3.9$ & $28.6 \pm 4.5$ & 0.131 \\
\hline $\begin{array}{l}\text { History of SLE } \\
(y r, \text { mean } \pm S D)\end{array}$ & $5.7 \pm 4.3$ & $5.8 \pm 4.4$ & $4.5 \pm 4.1$ & 0.091 \\
\hline $\begin{array}{l}\text { History of therapeutic abortion } \\
\text { (frequency, mean } \pm \mathrm{SD} \text {, range) }\end{array}$ & $\begin{array}{l}0.04 \pm 0.2 \\
(0-2)\end{array}$ & $\begin{array}{l}0.04 \pm 0.2 \\
(0-1)\end{array}$ & $\begin{array}{l}0.08 \pm 0.4 \\
(0-2)\end{array}$ & 0.657 \\
\hline $\begin{array}{l}\text { History of spontaneous } \\
\text { abortion } \\
\text { (frequency, mean } \pm \mathrm{SD} \text {, range) } \\
\text { Region }\end{array}$ & $\begin{array}{l}0.4 \pm 0.9 \\
(0-7)\end{array}$ & $\begin{array}{l}0.4 \pm 1.0 \\
(0-7)\end{array}$ & $\begin{array}{l}0.3 \pm 0.6 \\
(0-7)\end{array}$ & 0.687 \\
\hline City & $237(70.1)$ & $210(70.0)$ & $27(71.1)$ & 0.894 \\
\hline Rural & $101(29.9)$ & $90(30.0)$ & $11(28.9)$ & \\
\hline Nullipara & $291(86.1)$ & $258(86.0)$ & $33(86.8)$ & 0.888 \\
\hline Pre-pregnancy hypertension & $10(3.0)$ & $6(2.0)$ & $4(10.5)$ & $0.016^{*}$ \\
\hline Unplanned pregnancy & $45(13.3)$ & $32(10.7)$ & $13(34.2)$ & $0.000^{*}$ \\
\hline \multicolumn{5}{|l|}{ SLE clinical features } \\
\hline Renal disorder & $97(28.7)$ & $76(25.3)$ & $21(55.3)$ & $0.000^{*}$ \\
\hline Mucocutaneous & $106(31.4)$ & $94(31.3)$ & $12(31.6)$ & 0.975 \\
\hline Hematologic disorder & $66(19.5)$ & $53(17.7)$ & $13(34.2)$ & $0.015^{*}$ \\
\hline Neurologic disorder & $5(1.5)$ & $3(1.0)$ & $2(5.3)$ & 0.181 \\
\hline Arthritis & $70(20.7)$ & $63(21.0)$ & $7(18.4)$ & 0.712 \\
\hline Serositis & $17(5.0)$ & $10(3.3)$ & $7(18.4)$ & $0.001^{*}$ \\
\hline \multicolumn{5}{|l|}{ Laboratory features during pregnancy } \\
\hline $\begin{array}{l}\text { 24h-Urinary protein } \\
(\mathrm{g}, \text { mean } \pm \mathrm{SD})\end{array}$ & $1.04 \pm 2.43$ & $0.6 \pm 1.5$ & $4.3 \pm 4.9$ & $0.000^{*}$ \\
\hline Anti-dsDNA & $261(77.2)$ & $226(75.3)$ & $35(92.1)$ & $0.020^{*}$ \\
\hline Anti-Ro/SSA & $150(44.4)$ & $132(44.0)$ & $18(47.4)$ & 0.694 \\
\hline Anti-La/SSB & $47(13.9)$ & $41(13.7)$ & $6(15.8)$ & 0.722 \\
\hline Anti-Sm & $20(5.9)$ & $16(5.3)$ & $4(10.5)$ & 0.361 \\
\hline aPL & $46(13.6)$ & $38(12.7)$ & $8(21.1)$ & 0.156 \\
\hline Hypocomplementania- $C_{3}$ & $90(26.6)$ & $62(20.7)$ & $28(73.7)$ & $0.000^{*}$ \\
\hline Hypocomplementania- $\mathrm{C}_{4}$ & $60(17.8)$ & $45(15.0)$ & $15(39.5)$ & $0.000^{*}$ \\
\hline
\end{tabular}

10.1136/lupus-2019-|sm.250

\begin{tabular}{|c|c|c|c|}
\hline Variables & Risk Factors Included Individually & Risk Factors Included Simultaneously & $\begin{array}{l}\text { Risk Factors Selected Using } \\
\text { Stepwise Regression }\end{array}$ \\
\hline & $\mathrm{OR}(95 \% \mathrm{Cl})$ & $\mathrm{OR}(95 \% \mathrm{Cl})$ & $\mathrm{OR}(95 \% \mathrm{Cl})$ \\
\hline Unplanned pregnancy & $4.33(1.71-11.00){ }^{* *}$ & $3.01(0.90-10.02)$ & $2.84(1.12-7.22)^{*}$ \\
\hline Pre-pregnancy hypertension & $6.45(1.60-26.06)^{* *}$ & $5.24(0.74-37.38)$ & - \\
\hline Hypocomplementania- $C_{3}$ & $11.43(5.15-25.33)^{* *}$ & $7.09(2.60-19.36)^{* *}$ & $5.46(2.30-12.97){ }^{* *}$ \\
\hline Hypocomplementania- $\mathrm{C}_{4}$ & $3.80(1.81-7.98)^{\star \star}$ & $0.56(0.19-1.60)$ & - \\
\hline Renal disorder & $3.58(1.76-7.28){ }^{* *}$ & $0.33(0.09-1.15)$ & - \\
\hline Hematologic disorder & $2.19(1.02-4.69)^{*}$ & $0.90(0.32-2.53)$ & - \\
\hline Anti-dsDNA & $3.62(1.07-12.17){ }^{*}$ & $2.58(0.65-10.24)$ & - \\
\hline \multicolumn{4}{|l|}{ 24h-Urinary protein } \\
\hline urinary protein $<0.3 \mathrm{~g} / 24$ hour & 1 & 1 & 1 \\
\hline $0.3 \leq$ urinary protein $<1.0 \mathrm{~g} / 24$ hour & $3.34(1.05-10.68)^{*}$ & $3.23(0.90-11.65)$ & $2.10(0.63-6.95)$ \\
\hline urinary protein $>1.0 \mathrm{~g} / 24$ hour & $14.85(6.25-35.31)^{* *}$ & $16.20(3.90-67.29)^{* *}$ & $5.89(2.30-15.06) * *$ \\
\hline
\end{tabular}

NOTE: ${ }^{*} \mathrm{p}<0.05 ;{ }^{* *} \mathrm{p}<0.01$; Multivariable models adjusted for age at conception (continuous), history of SLE (continuous), history of therapeutic abortion (continuous), history of spontaneous abortion (continuous), region (city vs rural), nullipara (nullipara vs multipara) 
Abstract 250 Table 3 Adjusted odds ratio and B coefficient from cohort with multivariable logistic regression model and corresponding risk score

\begin{tabular}{llll}
\hline Variables & Ajusted OR & B & Score \\
\hline $\begin{array}{l}\text { Unplanned pregnancy } \\
\quad \text { Planned pregnancy }\end{array}$ & 1 & & 0 \\
$\quad \begin{array}{l}\text { Unplanned pregnancy } \\
\text { Hypocomplementania-C }\end{array}$ & 2.84 & 1.04 & 1 \\
$\quad \begin{array}{l}\text { Non-HypocomplementaniaC } \\
\text { HypocomplementaniaC }\end{array}$ & 1 & & 0 \\
$\begin{array}{l}\text { 24h-Urinary protein } \\
\text { Urinary protein<0.3 g/24 hour }\end{array}$ & 5.46 & 1.70 & 2 \\
$\begin{array}{l}\text { 0.3 Urinary protein<1.0 g/24 hour } \\
\text { Urinary protein } \geq 1.0 \mathrm{~g} / 24 \text { hour }\end{array}$ & 2.10 & & 0.74 \\
\hline
\end{tabular}

Abstract 250 Table 4 The risk classification for fetal loss according to the risk score system

\begin{tabular}{lllll}
\hline Risk & N & $\%$ & Fetal loss(N) & Fetal loss(\%) \\
\hline Low risk (0-3) & 295 & $87.3 \%$ & 15 & $5.1 \%$ \\
High risk $(>3)$ & 43 & $12.7 \%$ & 23 & $53.5 \%$ \\
Total & 338 & $100 \%$ & 38 & $11.2 \%$ \\
\hline $\mathrm{p}<0.01$ & & & &
\end{tabular}

Background Systemic lupus erythematosus (SLE) is a multi-system autoimmune disease, and it primarily affects women of childbearing age. While numerous studies have identified risk factors for fetal loss in pregnant women with SLE, results varied among studies. It is essential and helpful if the clinician is able to predict the risk of fetal loss in pregnant patients with SLE in the early stages of gestation, which can allow special monitoring and treatment as early as possible. However, a few studies have proposed such a predictive model or risk score.

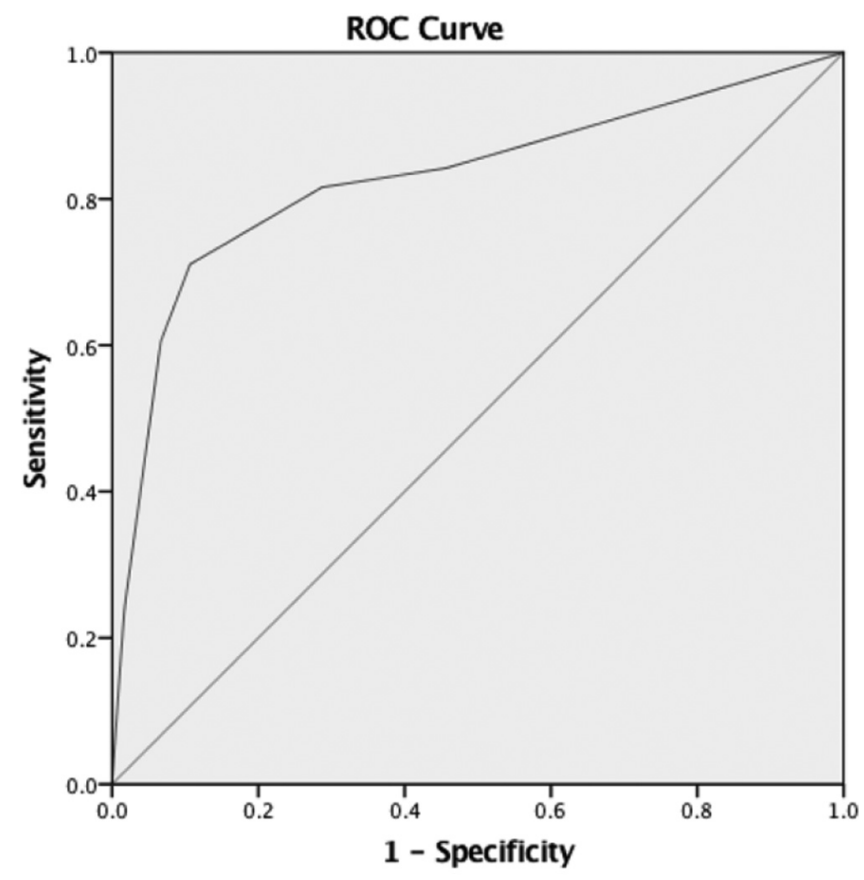

Diagonal segments are produced by ties.

Abstract 250 Figure 1 Diagonal segments are produced by ties

We therefore sought to develop a predictive model for fetal loss in women with SLE.

Methods A retrospective observational study of 338 pregnancies with SLE at a tertiary medical center was performed from September 2011 to May 2017, and relevant medical records were reviewed. Multiple gestations and artificial abortions were excluded for personal reasons. A stepwise regression to identify the predictors related to the fetal loss and coefficient B of each variable was used to develop a predictive model and make a corresponding risk classification. The Hosmer-

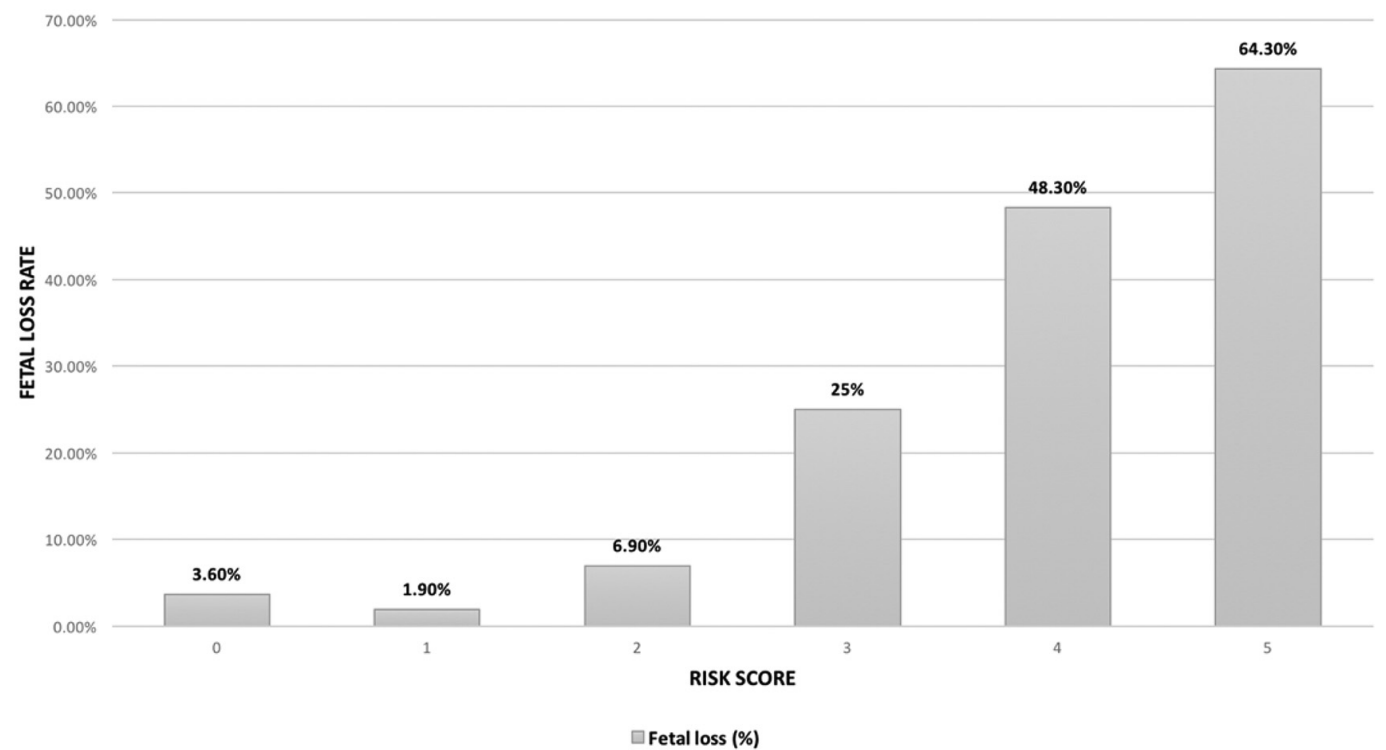

Abstract 250 Figure 2 Score - morbitdity of fetal loss 
Lemeshow test, Omnibus test and area under the receiveroperating characteristic (ROC) curve (AUC) were used to assess the goodness-of-fit and discrimination of the predictive model. A 10-fold cross validation was used to assess the model for over-fitting.

Results Unplanned pregnancies (OR 2.84, 95\% CI=1.127.22), C3 hypocomplementemia (OR 5.46, 95\% CI=2.30$12.97)$, and 24 hr-urinary protein level $(0.3$ protein $<1.0 \mathrm{~g} /$ 24 hour: OR 2.10, 95\% CI=0.63-6.95; protein $1.0 \mathrm{~g} / 24$ hour: OR 5.89, 95\%CI=2.30-15.06) were selected by the stepwise regression. The Hosmer-Lemeshow test resulted in $\mathrm{p}=0.325$; the Omnibus test resulted in $\mathrm{p}<0.001$ and the AUC was $0.829(95 \% \mathrm{CI}=0.744-0.91)$ in the regression model. The corresponding risk score classification was divided into low risk (0-3) and high risk groups (>3), with a sensitivity of $60.5 \%$, a specificity of $93.3 \%$, positive likelihood ratio of 9.03 and negative likelihood ratio of 0.42 .

Conclusions A predictive model for fetal loss in women with SLE was developed using the timing of conception, C3 complement and 24 hr-urinary protein level. This model may help clinicians in identifying women with high risk pregnancies, thereby carrying out monitoring or/and interventions for improving fetal outcomes.

Funding Source(s): The work was supported by funding from Shanghai Municipal Commission of Health and Family Planning (Grant no. 2017ZZ02016 and 15GWZK0701).

\section{TYPE II BUT NOT TYPE I INTERFERON SIGNIFIES CLINICAL RESPONSE TO USTEKINUMAB IN PATIENTS WITH SYSTEMIC LUPUS ERYTHEMATOSUS}

\begin{abstract}
${ }^{1}$ Jarrat Jordan*, ${ }^{1}$ Kristen Sweet, ${ }^{1}$ Matteo Cesaroni, ${ }^{1}$ Keying Ma, ${ }^{1}$ Carol Franks, ${ }^{1}$ Logmane Seridi, 'Jessica Schreiter, ${ }^{1}$ Robert Gordon, ${ }^{2}$ Peter Lipsky, ${ }^{3}$ Ronald van Vollenhoven, ${ }^{4}$ George C Tsokos, ${ }^{5}$ Bevra H Hahn, ${ }^{1}$ Shawn Rose, ${ }^{1}$ Frédéric Baribaud, ${ }^{1}$ Matthew J Loza, ${ }^{1}$ Kim Campbell. 'Janssen Research and Development, LLC; ${ }^{2}$ AMPEL BioSolutions; ${ }^{3}$ Amsterdam Rheumatology and Immunology Center; ${ }^{4}$ Department of Medicine, Beth Israel Deaconess Medical Center, Harvard Medical School; ${ }^{5}$ University of California, Los Angeles
\end{abstract}

\subsection{6/lupus-2019-Ism.251}

Background Treatment with ustekinumab (UST), an anti-IL-12/ 23, p40-neutralizing monoclonal antibody, improved global and organ-specific measures of disease activity in a randomized, placebo (PBO)-controlled trial of patients with active SLE (NCT02349061). ${ }^{1}$ Type I interferon (IFN-I) and type II IFN (IFN-gamma) are elevated in a subset of SLE patients. Although targeting IFN-I (anifrolumab) has demonstrated inconsistent efficacy and a preliminary study with anti-IFNgamma mAb (AMG811) failed to establish benefit, ${ }^{2} 3$ we sought to determine if UST affects either pathway and if those effects correlated with a positive SRI-4 response at wk24.

Methods A phase-2, PBO-controlled study enrolled 102 adults with seropositive SLE (SLICC criteria) and active disease (baseline SLEDAI score 6 and 1 BILAG A and/or 2 BILAG B scores) despite standard-of-care therapy. ${ }^{1}$ Gene expression analysis using a 21 gene IFN-I gene signature (IGS) ${ }^{4}$ or IFNgamma signature ${ }^{5}$ was performed by microarray analysis using whole blood PAXgene RNA samples. Serum IFN-gamma and IFN- levels were assessed using MSD (IFN-gamma) and Quanterix (IFN-).

Results Serum IFN-gamma and IFN- and the IGS were elevated at baseline in SLE compared to healthy controls $(p<0.0001)$. IGS was increased in approximately $67 \%$ of the
SLE patients at baseline. No decrease was observed with IFNprotein or IGS levels after treatment with either UST or PBO. Whereas the proportion of patients achieving an SRI-4 response at wk24 was numerically greater in the IGS low patients $(81.8 \%$ UST vs. $54.5 \%$ PBO) versus IGS high $(48.6 \%$ UST vs. $20 \% \mathrm{PBO})$, the magnitude of the treatment effect (UST vs. PBO) was similar in both subsets (IGS low effect size $=27.3 \%$ vs. IGS high effect size $=28.6 \%$ ). Despite similar baseline levels, UST-treated patients achieving an SRI-4 response at wk24 exhibited a significant decrease in IFNgamma protein versus non-responders $(p<0.05)$ at 4 and 8 wks and IFN-gamma gene signature at 4 wks $(\mathrm{p}<0.0001)$ and 24 wks $(\mathrm{p}<0.05)$ post-dosing.

Conclusions In this SLE trial population which had significant upregulation of IFN-I at baseline, clinical response to UST was not associated with IFN-I reduction. In contrast, a significant decrease in IFN-gamma protein and gene signature was associated with UST response. These findings suggest that a broad population of SLE patients may respond to UST regardless of baseline IFN-I status. Moreover, UST may have affected TH1 responses in SLE since IFN-gamma levels decreased following treatment.

Funding Source(s): Janssen Research and Development, LLC supported this study

\section{REFERENCES}

1. VanVollenhoven RF. Lancet 2018;392:1330.

2. Furie R. Arthritis Rheumatol 2017:69:376.

3. Boedigheimer MJ. Lupus Sci Med 2017;4:e000226.

4. Yao Y. Human Genomics Proteomics 2009. doi:10.4061/2009/374312

5. Welcher AA. Arthritis \& Rheumatol 2015;67:2713.

\section{PAP SCREENING RATES IN SYSTEMIC LUPUS ERYTHEMATOSUS WOMEN AT AN ACADEMIC CENTER COMPARED TO NON-SLE WOMEN WITH RACIAL COMPARISONS}

Ann Igoe*, Malahat Movahedian, Leila Muhieddine, Stanley Ballou, Yasir Tarabichi, Peter Greco, David Kaelber. Metrohealth hospital, Case Western Reserve

\subsection{6/lupus-2019-Ism.252}

Background Compared with the general population, women with systemic lupus erythematosus (SLE) tend to have higher rates of cervical neoplasia and pre-malignant lesions and in particular, SLE women treated with immunosuppressant therapies such as methotrexate, azathioprine and mycophenolate mofetil may be at even higher risk when compared to SLE women treated with antimalarials alone. Previous studies have suggested suboptimal cervical cancer screening among SLE patients and racial disparity studies have also shown that black SLE patients endure delayed SLE diagnosis and higher morbidity and mortality from SLE related disease compared to nonblack SLE patients.

Methods This was a cross-sectional study using electronic health records to identify women aged 21-65 years old with ICD code of SLE M32.9, positive ANA and who have prescription for hydroxychloroquine on their medication list. We compared this to controls (women 21-65 years of age with a ICD code of asthma ICD J45*, negative ANA and excluded patients with SLE diagnosis). For both groups we excluded patients who underwent hysterectomy with removal of the cervix. We used statistical calculator to ' $\mathrm{N}-1$ ' Chi-squared test

Results Much higher proportion of SLE women are overdue for pap smears compared to non SLE women $(60.09 \%$ vs 